Article

\title{
The Influence of Soil Acidity on the Physiological Responses of Two Bread Wheat Cultivars
}

\author{
Brigitta Tóth $^{1, *}$, Csaba Juhász ${ }^{2}$, Maryke Labuschagne ${ }^{3}$ and Makoena Joyce Moloi ${ }^{3}$ \\ 1 Institute of Food Science, University of Debrecen, 138 Böszörményi St., 4032 Debrecen, Hungary \\ 2 Arid Land Research Centre, University of Debrecen, 138 Böszörményi St., 4032 Debrecen, Hungary; \\ juhasz@agr.unideb.hu \\ 3 Department of Plant Sciences, University of the Free State-Main Campus, P.O. Box 339, Bloemfontein 9300, \\ South Africa; LabuscM@ufs.ac.za (M.L.); MoloiMJ@ufs.ac.za (M.J.M.) \\ * Correspondence: btoth@agr.unideb.hu; Tel.: +3630/2738842
}

Received: 23 September 2020; Accepted: 30 October 2020; Published: 31 October 2020

check for updates

\begin{abstract}
The recent study was conducted to examine the influence of acidic soil on the activities of ascorbate (APX) and guaiacol peroxidase (POD), proline, protein as well as malon-dialdehyde (MDA) content, in two commercial spring wheat cultivars (PAN3497 and SST806) at different growth stages (tillering and grain filling). A cultivar effect was significant only for MDA content, while the treatment effect was highly significant for proline, protein, and MDA. The sampling time effect was significant for most characteristics. MDA, antioxidative capacity, as well as protein content increased with maturity. At grain filling, MDA and proline contents were significantly higher at $\mathrm{pH} 5$ than $\mathrm{pH}$ 6 and 7 for both cultivars, with the highest content in SST806. Similarly, SST806 had significantly higher APX and POD when growing at $\mathrm{pH}$ 5. There were no significant differences in protein content at grain filling between either genotype or treatments affected by low $\mathrm{pH}$. This study showed that growth stage and soil $\mathrm{pH}$ influence the rate of lipid peroxidation as well as the antioxidative capacity of wheat, with a larger effect at grain filling, at pH 5. Although SST806 had higher proline, POD, and APX content than PAN3497 at this growth stage, this coincided with a very high MDA content. This shows that the high antioxidative capacity observed here, was not associated with a reduction of lipid peroxidation under low soil $\mathrm{pH}$. Further research should, therefore, be done to establish the role of the induced antioxidant system in association with growth and yield in wheat.
\end{abstract}

Keywords: antioxidative enzyme activity; low $\mathrm{pH}$; proline; protein; wheat

\section{Introduction}

Climate change has severe consequences on the natural environment and agricultural production, leading to poverty and food insecurity [1]. The indirect impact of such alterations include a shift in cropland distribution, while a direct effect involves, among others, sulfidic wetland drying (because of climate change-induced drought). As a result, climate change has a catalytic effect on the changes in soil quality [2], specifically soil acidification, which is a worldwide problem, but especially so in Africa and Europe. Africa contributes a higher proportion (16.7\%) of global acidic soils compared to Europe (9.9\%) [3,4]. In parts of South Africa, for example, the KwaZulu-Natal province, $85 \%$ of soils have a $\mathrm{pH}$ of less than five [5], which has a significant impact on crop production, leading to yield losses of up to $70 \%$ [6]. The extent of yield reduction depends on the level of hydrogen ions (which affects plant growth and development) [7-9], climatic conditions and genetic background of the cultivar. In addition, the combination of $\mathrm{H}^{+}$-toxicity, nutrient deficiency and reduced water uptake influences growth negatively [10]. Many studies associate soil acidification with nitrogen fertilizer 
over-application [11-13], acid rain [13-15], changes in soil physical properties [16], plant residues [17], and changes in soil chemistry [18] as the main common reasons worldwide.

Acid soil affects phosphorus uptake, root length, and mean root diameter [19]. Furthermore, low soil $\mathrm{pH}$ could influence the levels of reactive oxygen species (ROS) [20] such as singlet oxygen $\left({ }^{1} \mathrm{O}_{2}\right)$, superoxide anion $\left(\mathrm{O}_{2-}\right)$, hydrogen peroxide $\left(\mathrm{H}_{2} \mathrm{O}_{2}\right)$, and hydroxyl radical $(\mathrm{OH})$. These radicals are able to oxidize vital cellular ultrastructure and give rise to oxidative damage and devastation of cellular organelles [21]. For instance, Zhang et al. [22] reported that lipid peroxidation and $\mathrm{H}_{2} \mathrm{O}_{2}$ concentration increased in rice seedling when $\mathrm{H}^{+}$concentration was high. Similarly, growing Plantago in $\mathrm{pH} 4$ soil contributed to enhanced lipid peroxidation [23]. Yang et al. [24] indicated that low soil pH enhanced the membrane permeability in Eucalyptus leaves. Contrary to this, $\mathrm{pH} 4$ did not affect $\mathrm{H}_{2} \mathrm{O}_{2}$, malondialdehyde (MDA), electrolyte leakage, and protein oxidation in the roots and leaves of Plantago algarbiensis and P. almogravensis [25].

To compensate for the unfavorable influence of free radicals, plants possess an antioxidative system (non-enzymatic and enzymatic) aimed at reducing the effect of oxidative stress [26,27]. The activity of antioxidant enzymes was associated with low soil $\mathrm{pH}$ in cucumber, citrus, and rice $[22,28,29]$. Soil acidity selectively increased ascorbate peroxidase (APX) while it reduced superoxide dismutase (SOD) and catalase (CAT) activity in rice roots [22]. Such selective induction of antioxidative enzymes (monodehydroascorbate reductase, guaiacol peroxidase, APX, and glutathione reductase) was also observed in cucumber [28]. In some instances, however, increase in the antioxidative enzyme activities was not sufficient to protect plants against oxidative damage [23]. Results of a study in the leaves and roots of $P$. algarbiensis and $P$. almogravensis contradicted such findings, where the antioxidative enzymes were not affected by low soil $\mathrm{pH}[25,30]$.

To date, most studies have focused on the influence of soil acidity on plant growth and yield. There is limited knowledge of the influences of low soil $\mathrm{pH}$ on the physiological aspects of wheat, especially on leaves. Therefore, our experiment was set to investigate the influence of low soil $\mathrm{pH}$ on lipid peroxidation, protein and proline contents as well as on antioxidant enzymes (ascorbate oxidase and guaiacol peroxidase) activities, in the leaves of two South African hard spring wheat cultivars, at two growth stages, tillering and grain filling.

\section{Results}

The rate of lipid peroxidation was measured by the amount of MDA used in plants grown in low $\mathrm{pH}$ soil. Compared to the $\mathrm{pH} 7$ treatment, the highest differences in MDA content were observed at pH 5 for PAN3497 (34\%) and SST806 (39\%) at the grain filling stage, while at tillering, significantly higher levels of MDA was recorded in PAN3497 only. The levels of lipid peroxidation were higher at grain filling than the tillering stage for both genotypes. For both growth stages and genotypes, the $\mathrm{pH}$ 6 treatment was not significantly different from $\mathrm{pH} 7$ (Figure 1).

At grain filling, cultivars responded differently to $\mathrm{pH}$ treatments, where PAN3497 had a significant increase in APX activity at pH 6 while SST806 had highly significantly increased activity at pH 5 . In contrast to this, at the tillering stage, APX activity did not change significantly for any of the $\mathrm{pH}$ treatments and genotypes (Figure 2). 


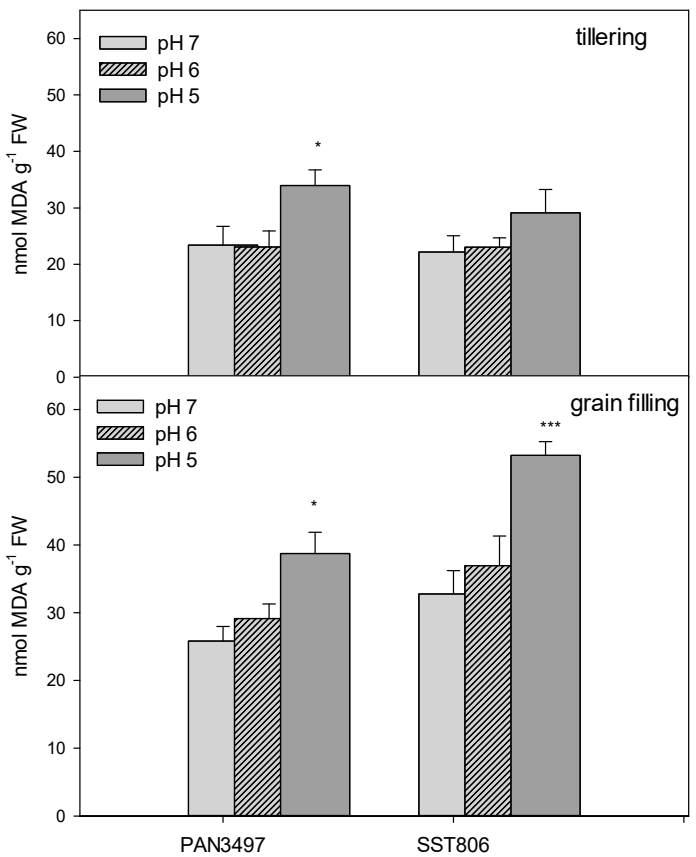

Figure 1. The MDA content of PAN3497 and SST806 grown at three soil pH levels (pH 7, 6, and 5), with two sampling times (tillering and grain filling). Values are the averages of three biological and technical repetitions \pm SE. Significant difference compared to $\mathrm{pH} 7:{ }^{*} p<0.05,{ }^{* * *} p<0.001$.

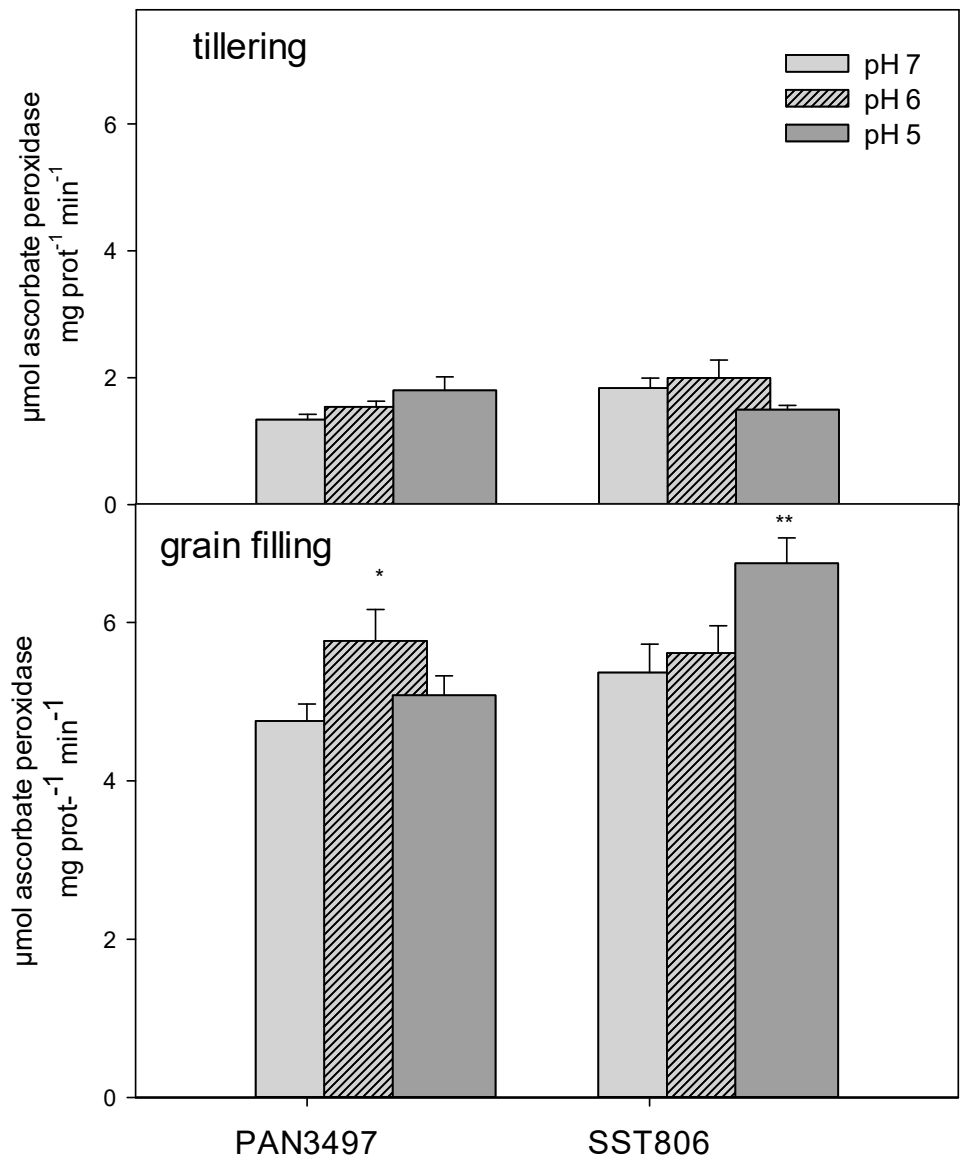

Figure 2. The APX activity of PAN3497 and SST806 grown at three soil pH levels (pH 7, 6, and 5), with two sampling times (tillering and grain filling). Values are the averages of three biological and technical repetitions \pm SE. Significant difference compared to $\mathrm{pH} 7:{ }^{*} p<0.05,{ }^{* *} p<0.01$. 
Higher tetraguaiacol content (representing high peroxidase activity) was measured during grain filling than tillering (Figure 3). Peroxidase activity for PAN3794 showed no significant changes for either growth stage. Contrary to this, a highly significant reduction in peroxidase activity was observed for SST806 at pH 5 during tillering. However, at grain filling, activity was significantly higher at pH 5 .

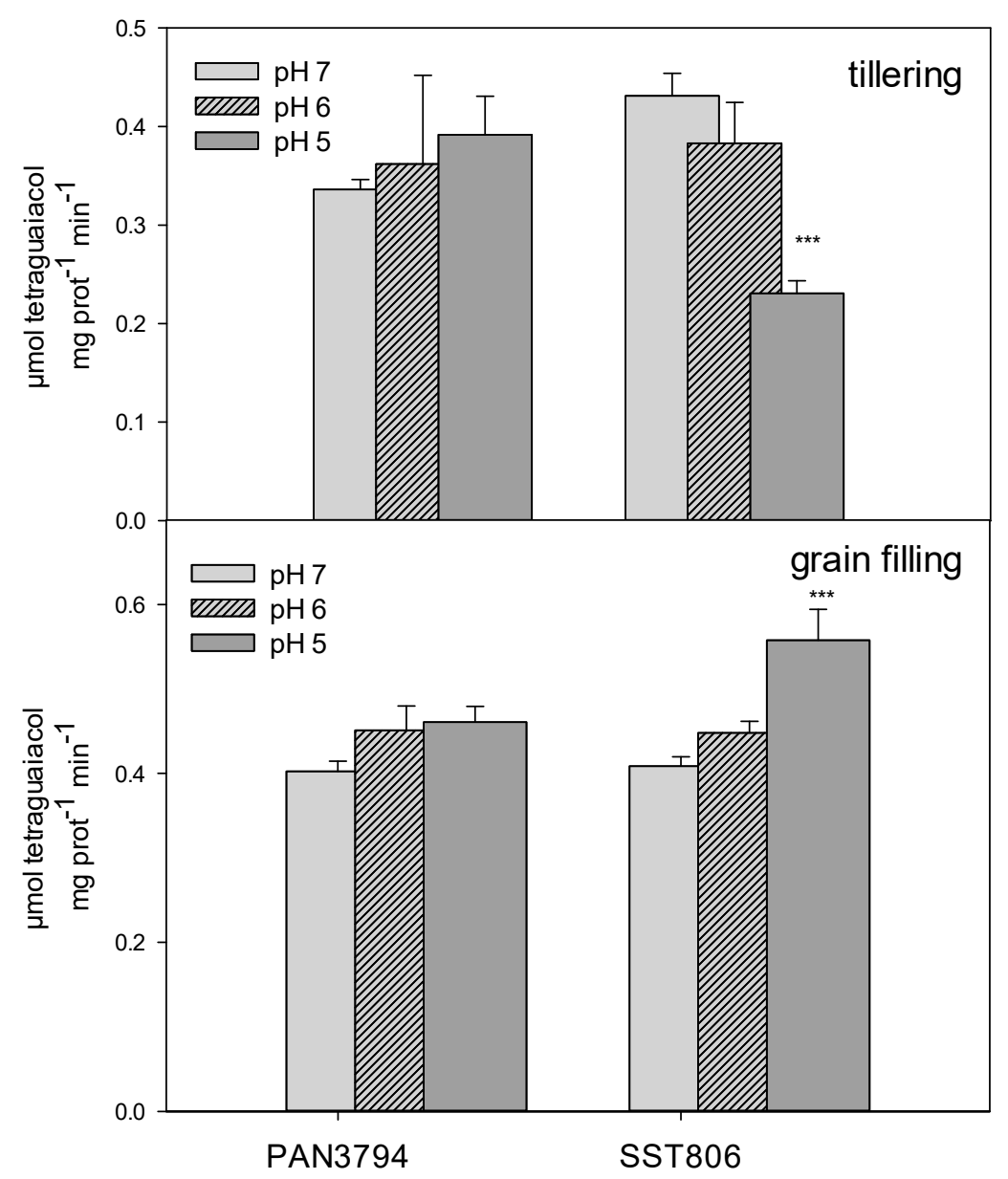

Figure 3. The peroxidase (POD) activity of PAN3497 and SST806 grown at three soil pH levels (pH 7, 6, and 5), with two sampling times (tillering and grain filling). Values are the averages of three biological and technical repetitions \pm SE. Significant difference compared to $\mathrm{pH} 7:{ }^{* * *} p<0.001$.

Proline content increased with a decrease in the $\mathrm{pH}$ for both genotypes at grain filling. This increase, however, was significant only at $\mathrm{pH} 5$. The pattern, however, changed at the tillering stage where pH 6 influenced proline accumulation negatively. For PAN3497, there were no significant differences between $\mathrm{pH} 7$ and 5. SST806 displayed differences between the treatments, however, the differences were not significant (Figure 4). 


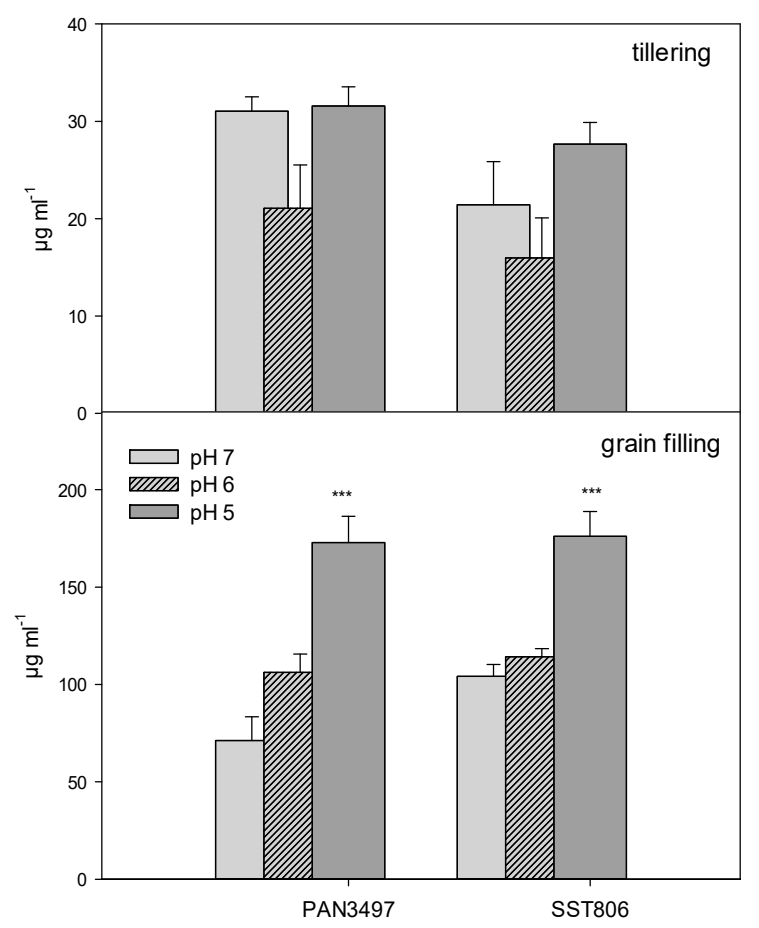

Figure 4. Proline content in leaves of PAN3497 and SST806 grown at three soil pH levels (pH 7, 6, and 5), with two sampling times (tillering and grain filling). Values are the averages of three biological and technical repetitions \pm SE. Significant difference compared to $\mathrm{pH}$ 7: ${ }^{* * *} p<0.001$.

Although protein content increased with a decrease in $\mathrm{pH}$ for SST806, the treatments were not significantly different at the tillering stage. For PAN3497 at tillering, protein content was significantly decreased at $\mathrm{pH} 5$. In contrast, at grain filling, there were no significant differences between treatments or genotypes (Figure 5).

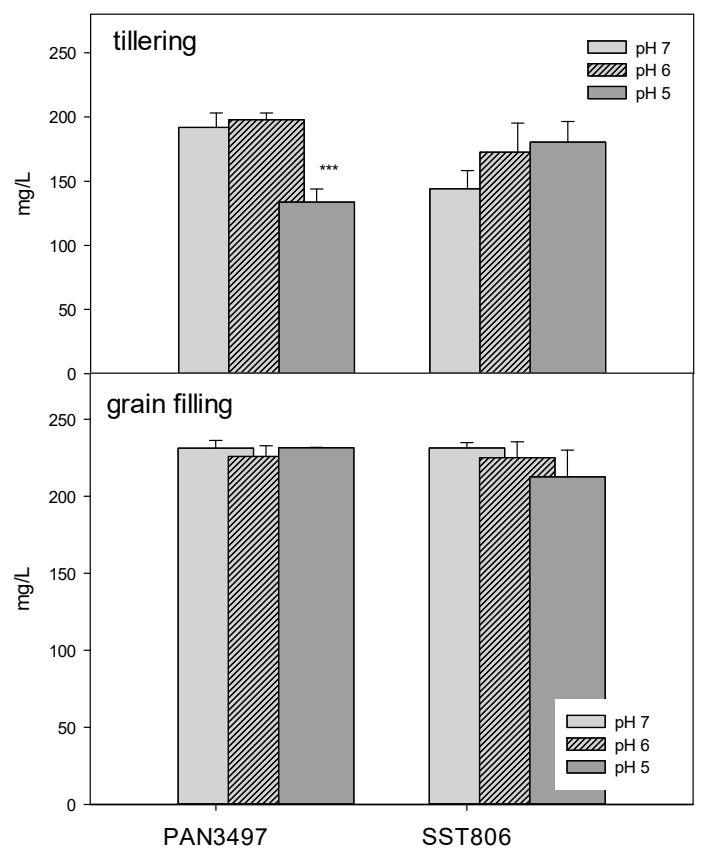

Figure 5. Protein content in leaves of PAN3497 and SST806 grown at three soil pH levels (pH 7, 6, and 5), with two sampling times (tillering and grain filling). Each value is the mean \pm standard error of three biological and technical replicates. Significant difference compared to $\mathrm{pH}$ 7: ${ }^{* *} p<0.001$. 
The cultivar effect was only significant $(p \leq 0.01)$ for MDA content. Based on ANOVA the influence of treatments were significant $(p \leq 0.001)$ on MDA, proline, and protein content and insignificant on APX and POD. Highly significant sampling time effects were measured for all characteristics. POD was the least influenced by the sampling time. The cumulative effects of cultivar and $\mathrm{pH}$ treatments significantly influenced the proline and protein content. In addition, a highly significant interaction was observed between cultivar and sampling times for MDA content. Treatment and sampling time interactions were significant for APX, POD, proline, and protein content (Table 1).

Table 1. The mean squares from the combined analysis of variance for ascorbate peroxidase activity, malondialdehyde content, peroxidase activity, proline, and protein content for two wheat cultivars, with three treatments over two sampling times.

\begin{tabular}{cccccccc}
\hline & $\begin{array}{c}\text { Cultivar } \\
\text { (C) }\end{array}$ & Treatment (T) & $\begin{array}{c}\text { Sampling } \\
\text { Times (S) }\end{array}$ & CxT & CxS & TxS & CxTxS \\
\hline APX & 1.91 & 1.58 & $281.91^{* * *}$ & 0.75 & 0.03 & $4.17^{* *}$ & 0.68 \\
MDA & $441.39^{* *}$ & $1055.19^{* * *}$ & $1144.73^{* * *}$ & 20.67 & $571.61^{* *}$ & 181.34 & 28.36 \\
POD & 0.00 & $0.01^{* * *}$ & $0.30^{* * *}$ & 0.01 & 0.01 & $0.06^{* *}$ & 0.01 \\
Proline & 612.26 & $17,677.81^{* * *}$ & $185,844.69^{* * *}$ & $1038.73^{*}$ & 2003.23 & $15,533.44^{*}$ & 833.11 \\
Protein & 485.68 & $1905.05^{*}$ & $62,151.63^{* * *}$ & $2011.45^{* *}$ & 679.57 & $4362.51^{* * *}$ & $3423.66^{* * *}$ \\
\hline$* p<0.05^{* *} p<0.01^{* * *} p<0.001^{*}$ APX & ascorbate peroxidase; MDA malondialdehyde; POD, peroxidase.
\end{tabular}

Table 2 shows the average values of the two genotypes. The $\mathrm{pH}$ treatments had no effect on POD. APX slightly increased with decreasing soil $\mathrm{pH}$. Decreasing soil $\mathrm{pH}$ inversely affected MDA content, which was highest for $\mathrm{pH}$ 5. Proline content significantly increased in all treatments, with the largest effect at $\mathrm{pH}$ 5. Protein content was the least for $\mathrm{pH} 5$ treatment.

Table 2. Average values of two genotypes and two sampling times for measured parameters for three treatments.

\begin{tabular}{ccccc}
\hline & $\begin{array}{c}\text { pH 7 } \\
\text { Mean } \pm \text { S.D. }\end{array}$ & $\begin{array}{c}\text { pH 6 } \\
\text { Mean } \pm \text { S.D. }\end{array}$ & $\begin{array}{c}\text { pH 5 } \\
\text { Mean } \pm \text { S.D. }\end{array}$ & LSD (0.05) \\
\hline APX & $3.32 \pm 2.03$ & $3.71 \pm 2.30$ & $3.78 \pm 2.56$ & 0.38 \\
MDA & $26.51 \pm 4.32$ & $28.05 \pm 6.60$ & $38.76 \pm 10.42$ & 3.71 \\
POD & $0.40 \pm 0.03$ & $0.41 \pm 0.05$ & $0.41 \pm 0.14$ & 0.03 \\
Proline & $57.10 \pm 38.22$ & $64.46 \pm 53.17$ & $102.17 \pm 83.80$ & 8.54 \\
Protein & $199.60 \pm 41.41$ & $206.00 \pm 23.03$ & $189.10 \pm 42.93$ & 9.65 \\
\hline
\end{tabular}

Values in columns are means \pm standard deviation; APX, ascorbate peroxidase; MDA, malondialdehyde; POD, peroxidase.

The genotype had no effect on POD. APX activity was insignificantly higher for SST806 compared to PAN3497. PAN3497 had a significantly lower MDA content than SST806, whilst the proline content was notably higher for SST806 compared to PAN3497 (Table 3). Protein content was significantly higher for PAN3497 compared to SST806.

Table 3. Average values for measured parameters in two genotypes with three treatments over two sampling times.

\begin{tabular}{cccc}
\hline & PAN3497 & SST806 & LSD (0.05) \\
\hline APX & $3.36 \pm 2.04$ & $3.84 \pm 0.11$ & 0.31 \\
MDA & $29.03 \pm 6.26$ & $33.19 \pm 11.14$ & 3.03 \\
POD & $0.40 \pm 0.05$ & $0.41 \pm 0.11$ & 0.03 \\
Proline & $72.58 \pm 58.97$ & $76.57 \pm 65.08$ & 6.97 \\
Protein & $202.00 \pm 37.36$ & $194.97 \pm 33.64$ & 7.88 \\
\hline
\end{tabular}

Values in columns are means \pm standard deviation; APX, ascorbate peroxidase; MDA, malondialdehyde; POD, peroxidase. 


\section{Discussion}

Exposure to abiotic stressors such as acidic soil conditions commonly results in the overproduction of reactive oxygen species (ROS) [31]. The increased activity of antioxidant enzymes is one of the first reactions as a response of plants to oxidative stress [10].

The few studies that have reported on the influence of oxidative stress catalyzed by acidic soil conditions were contradictory. Long et al. [29] stated that low $\mathrm{pH}$ influenced ROS more in roots than in leaves. Bhuyan et al. [32] stated that under acidic growing conditions, as well as during other abiotic stresses such as cold stress [33] wheat MDA content was higher. In this experiment, MDA content, APX and POD activity, proline, and protein content of wheat leaves significantly changed when plants were grown in $\mathrm{pH} 5$ soil. Moreover, a very strong cultivar effect was found. Significant changes were observed only at pH 5 in the case of SST806, while MDA concentration and POD activity significantly changed in PAN3497 at soil $\mathrm{pH} 6$.

Turhan et al. [34] found that the growth stage of a plant influences its response to abiotic stress, which was confirmed by the higher levels of proline, protein, and MDA content at grain filling than at the tillering stage in the current study. Firscher [35] also stated that the most sensitive development stages of wheat are stem elongation, after flowering, and grain filling. Dreccer et al. [36] showed that high temperatures and water imbalance influenced the production of barley, wheat, chickpea, and canola at tillering, stem elongation, and grain filling.

The effect of cultivar on MDA content was negligible, although SST806 had slightly higher values during grain filling. The sampling time effect was significant for the different traits. Nikolaeva et al. [37] stated that the activity of APX, proline, and MDA content of wheat leaves were influenced by cultivar, time of stress, and the phase of leaf development. This study showed similar results. The effects of the treatments were highly significant for MDA, proline, and protein content in this experiment. MDA and proline content was notably higher in the $\mathrm{pH} 5$ treatment, whilst protein content was reduced compared to $\mathrm{pH} 7$ conditions in this study. MDA content was higher by $95 \%$ when wheat was grown at $\mathrm{pH} 5.5$ compared to $\mathrm{pH} 7.0$ conditions [32].

Proline is a so-called non-enzymatic antioxidant. Its accumulation is caused by increased synthesis or moderated deterioration [38], which is one of the plants' reactions to abiotic stressors [39]. In this study, proline content was significantly higher at $\mathrm{pH} 5.0$ compared to $\mathrm{pH} 7.0$ in both cultivars. A higher concentration of proline is an indication that the plants are exposed to stressors [40]. The expression levels of the antioxidant (SOD, CAT, and POX) and proline genes responsible for scavenging or neutralizing ROS were identified in plants. The tolerance of plants to low $\mathrm{pH}$ soil is based on the expression of genes related to proline and antioxidant production [41].

Interestingly, proline may enhance the activity of some antioxidant enzymes, for instance, peroxidase [42]. APX activity was also stated to be enhanced under several stress conditions; e.g., Shi et al. [28] found that the activity of APX was higher when cucumber was grown at $\mathrm{pH} 4.5$ compared to $\mathrm{pH}$ 6.5. However, the current study did now show significant changes in APX activity. Furthermore, Zhang et al. [22] also published enhanced APX activity in rice roots at $\mathrm{pH}$ 2.5. They suggested that the activation of APX is a principal part in scavenging ROS and aids the adaptation of plants to acidic $\mathrm{pH}$.

According to Sanmartin et al. [43], oxidative stress can catalyze the expression of ascorbate oxidase (AOX), suggesting its role in regulating oxidative stress [44]. In the current study, the APX was significantly higher at $6 \mathrm{pH}$ in PAN3497 and also significantly higher in SST806 at pH 5.0 during the grain filling stage.

In conclusion, growth stages influence the rate of lipid peroxidation, as well as the antioxidative capacity of bread wheat cultivars with a larger effect at grain filling, making this a very important time for studying the effects of acidity stress at the biochemical level. Although SST806 had higher proline, POD, and APX levels, this coincided with a very high MDA content. This shows that the high antioxidative capacity observed here cannot be associated with the reduction of membrane damage under low soil $\mathrm{pH}$. This study should therefore be advanced to establish the role of the induced antioxidant system in association with the yield performance of these cultivars. The current 
research findings were obtained under controlled conditions in a glasshouse. Nitrogen leaching or other circumstances can affect results in field conditions.

\section{Materials and Methods}

\subsection{Green House Trial}

Two South-African bread wheat genotypes, PAN3497 and SST806, were sown in 2 L pots filled with $2 \mathrm{~kg}$ soil in the greenhouse (temperature was $18{ }^{\circ} \mathrm{C}$ during the night and $22-24{ }^{\circ} \mathrm{C}$ during the day) in a randomized complete block design with three factors ( $\mathrm{pH}$ treatments, genotypes, and sampling times) and three repetitions (20 pots per repetition where each pot contained three plants). The soil was collected at Bainsvlei (GPS S 29.05 S 26.11667 ${ }^{\circ}$, Bloemfontein, South Africa) from $1.5 \mathrm{~m}$ deep subsoil. The data of the soil analysis are shown in Table 4. Soil nitrogen content was determined with the classic Kjeldahl-method [45]. Soil phosphorus availability was measured with Bray 1 [46]. The amount of extractable cations and microelements were determined with the use of ammonium acetate, where $2.5 \mathrm{~g}$ soil and $25 \mathrm{~mL} 1 \mathrm{M}$ ammonium acetate was applied for the extraction. The concentration of cations was measured with an atomic adsorption spectrophotometer, based on Miller et al. [47]. The total organic carbon content of the soil was measured by the Walkley-Black method [48]. The soil texture (sand, clay, and silt \%) was determined with the Bouyoucos method [49]. To determine the soil density, the weight of $10 \mathrm{~cm}^{3}$ of dry soil was divided by its volume.

Table 4. Main parameters of the used soil.

\begin{tabular}{|c|c|}
\hline Parameters & Value \\
\hline $\mathrm{pH}_{\mathrm{H} 2 \mathrm{O}}$ & 6.8 \\
\hline sand $(\%)$ & 96 \\
\hline clay $(\%)$ & 4 \\
\hline silt $(\%)$ & 0 \\
\hline $\mathrm{CEC}\left(\mathrm{cmol}_{\mathrm{C}} \mathrm{kg}^{-1}\right)$ & 3.27 \\
\hline density $\left(\mathrm{g} \mathrm{cm}^{-1}\right)$ & 1.18 \\
\hline $\mathrm{C}(\%)$ & 0.04 \\
\hline $\mathrm{N}\left(\mathrm{mg} \mathrm{kg}^{-1}\right)$ & $<0.004$ \\
\hline $\mathrm{P}\left(\mathrm{mg} \mathrm{kg}^{-1}\right)$ & 26.5 \\
\hline $\mathrm{K}\left(\mathrm{mg} \mathrm{kg}^{-1}\right)$ & 163.6 \\
\hline $\mathrm{Ca}\left(\mathrm{mg} \mathrm{kg}^{-1}\right)$ & 13,630 * \\
\hline $\mathrm{S}\left(\mathrm{mg} \mathrm{kg}^{-1}\right)$ & 1.62 \\
\hline $\operatorname{Mg}\left(\mathrm{mg} \mathrm{kg}^{-1}\right)$ & 38.914 * \\
\hline $\mathrm{Na}\left(\mathrm{mg} \mathrm{kg}^{-1}\right)$ & $1.80 *$ \\
\hline $\mathrm{Fe}\left(\mathrm{mg} \mathrm{kg}^{-1}\right)$ & 4.82 \\
\hline $\mathrm{Zn}\left(\mathrm{mg} \mathrm{kg}^{-1}\right)$ & 0.71 \\
\hline $\mathrm{Cu}\left(\mathrm{mg} \mathrm{kg}^{-1}\right)$ & 0.60 \\
\hline $\mathrm{Mn}\left(\mathrm{mg} \mathrm{kg}^{-1}\right)$ & 21.39 \\
\hline
\end{tabular}

The experiment was conducted from June to the end of October 2018.

The following macro and micronutrient fertilization was applied for all treatments: $261 \mathrm{mg} \mathrm{L}^{-1}$ $\mathrm{KNO}_{3}, 210 \mathrm{mg} \mathrm{L}^{-1} \mathrm{~K}_{2} \mathrm{SO}_{4}, 87 \mathrm{mg} \mathrm{L}^{-1} \mathrm{NH}_{4} \mathrm{H}_{2} \mathrm{PO}_{4}, 758 \mathrm{mg} \mathrm{L}^{-1} \mathrm{Ca}\left(\mathrm{NO}_{3}\right)_{2}, 348 \mathrm{mg} \mathrm{L}^{-1} \mathrm{MgSO}_{4}, 3.45 \mathrm{mg}$ $\mathrm{L}^{-1} \mathrm{C}_{10} \mathrm{H}_{13} \mathrm{FeN}_{2} \mathrm{O}_{8}, 0.30 \mathrm{mg} \mathrm{L}^{-1} \mathrm{MnSO}_{4}, 0.13 \mathrm{mg} \mathrm{L}^{-1} \mathrm{ZnSO}_{4}, 0.62 \mathrm{mg} \mathrm{L}^{-1} \mathrm{H}_{3} \mathrm{BO}_{3}, 0.05 \mathrm{mg} \mathrm{L}^{-1} \mathrm{CuSO}_{4}$, $0.02 \mathrm{mg} \mathrm{L}^{-1} \mathrm{Na}_{2} \mathrm{MoO}_{4}$.

\subsection{Treatments}

For low soil pH treatments, sulfur (S) was applied at different concentrations. The control did not receive any $\mathrm{S}$. The $\mathrm{S}$ treatments were as follows: in order to the lower $\mathrm{pH}$ to $6,0.155 \mathrm{~g}$ of $\mathrm{S}$ was added per $\mathrm{kg}$ of soil; to lower the $\mathrm{pH}$ to $5,0.387 \mathrm{~g}$ of $\mathrm{S}$ was added per $\mathrm{kg}$ of soil. 
After the treatments, the soil was kept moist and incubated for four weeks with weekly $\mathrm{pH}$ measurements to ensure that the desired $\mathrm{pH}$ was reached. Sowing commenced after the soil incubation period.

\subsection{Sampling}

The youngest leaves were collected from the main stem at the tillering and grain filling stages. Thereafter, they were placed in liquid nitrogen and stored in an ultra-freezer at $70{ }^{\circ} \mathrm{C}$ until the determination of the measured parameters.

\subsection{Enzymes Assays}

The experiment followed the process from Pukacka and Ratajczak [50] to make the enzyme extracts. Samples $(1 \mathrm{~g})$ of each treatment were weighed, homogenized with liquid nitrogen and $5 \mathrm{~mL}$ of $50 \mathrm{mM}$ potassium phosphate buffer ( $\mathrm{pH}$ 7.0) was added. The buffer contained the following chemicals: $1 \mathrm{mM}$ EDTA, 2\% PVPP, $0.1 \%$ Triton X-100 and $1 \mathrm{mM}$ ascorbate. To obtain the supernatant used for examination, the resulting extract was centrifuged at $15,000 \times g$ for $20 \mathrm{~min}$ at $4{ }^{\circ} \mathrm{C}$.

The APX assay was carried out based on Mishra et al. [51] with some changes to the composition of the reaction mixture. Each $1 \mathrm{~mL}$ of mixture contained $470 \mu \mathrm{L} 50 \mathrm{mM}$ phosphate buffer (pH 7.0), $250 \mu \mathrm{L}$ $0.1 \mathrm{mM} \mathrm{H}_{2} \mathrm{O}_{2}, 200 \mu \mathrm{L} 0.5 \mathrm{mM}$ sodium ascorbate, $50 \mu \mathrm{L} 0.1 \mathrm{mM}$ EDTA and $30 \mu \mathrm{L}$ enzyme. The APX activity was measured from the decrease in absorbance due to ascorbate oxidation. The absorbance was measured at $290 \mathrm{~nm}$ for $5 \mathrm{~min}$ at $20^{\circ} \mathrm{C}$ against a blank, which contained $50 \mathrm{mM}$ phosphate buffer instead of the enzyme. Each sample was measured three times. To calculate the enzyme activity, an extinction coefficient of $2.8 \mathrm{mM}^{-1} \mathrm{~cm}^{-1}$ was applied.

To measure the POD activity, the study used a method published by Zieslin and Ben-Zaken [52] with some modifications to the amount of chemicals used in the reaction mixture. The modified mixture had $50 \mu \mathrm{L} 0.2 \mathrm{M} \mathrm{H}_{2} \mathrm{O}_{2}, 100 \mu \mathrm{L} 50 \mathrm{mM}$ guaiacol, $340 \mu \mathrm{L}$ distilled $\mathrm{H}_{2} \mathrm{O}, 500 \mu \mathrm{L} 80 \mathrm{mM}$ phosphate buffer (pH 5.5), and $10 \mu \mathrm{L}$ enzyme. The POD activity was determined based on the concentration of generated tetraguaiacol. The absorbance of the reaction mixture was read at $470 \mathrm{~nm}$ for $3 \mathrm{~min}$ at $30^{\circ} \mathrm{C}$. All the above mentioned chemicals were used for the blank, but $50 \mathrm{mM}$ phosphate buffer was used instead of the enzyme. To calculate the concentration of tetraguaiacol created, the extinction coefficient was $26.6 \mathrm{mM}^{-1} \mathrm{~cm}^{-1}$.

The study used the method of Bradford [53] to measure protein content for the enzyme extract.

The rate of lipid peroxidation was deduced by measuring the quantity of malondialdehyde (MDA) generated in the chemical assay, using the method described by Heath and Packer [54]. Wheat leaves $(100 \mathrm{mg}$ ) were homogenized with liquid nitrogen, and $1 \mathrm{~mL} 0.25 \%$ thiobarbituric acid (TBA) and $10 \%$ trichloroacetic acid (TCA) was added. The samples were centrifuged at $10,800 \times g$ for 25 min at $4{ }^{\circ} \mathrm{C}$ and the supernatants were used. The reaction was generated by the use of $0.2 \mathrm{~mL}$ supernatant and $0.8 \mathrm{~mL}$ $20 \%$ TCA, then $0.5 \%$ TBA was added to a clean Eppendorf tube. The mixture was vortexed, heated at $95^{\circ} \mathrm{C}$ for $30 \mathrm{~min}$ and immediately cooled on ice. This was followed by centrifugation at $10,800 \times g$ for $10 \mathrm{~min}$ at $4{ }^{\circ} \mathrm{C}$. The absorbance was read at $532 \mathrm{~nm}$ and $600 \mathrm{~nm}$. The amount of malondialdehyde was computed with the use of an extinction coefficient of $155 \mathrm{mM}^{-1} \mathrm{~cm}^{-1}$.

The proline content in the leaves was measured based on Carillo and Gibon [55]. Fresh wheat

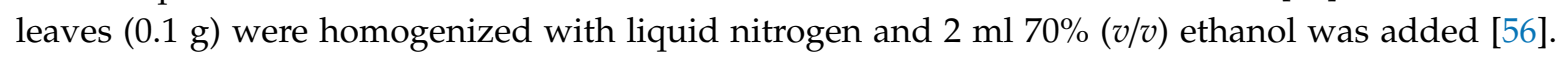
The $1 \mathrm{~mL}$ reaction mix ( $1 \%$ ninhydrin in $60 \%(v / v)$ acetic acid) was added to $500 \mu \mathrm{L}$ ethanolic extract and placed into $1.5 \mathrm{~mL}$ Eppendorf tubes, which were shaken and kept in a $95^{\circ} \mathrm{C}$ water bath for $20 \mathrm{~min}$. Afterward, samples were cooled on ice and centrifuged at 12,000 $\mathrm{g}$ for $1 \mathrm{~min}$. The absorbance of the samples was measured at $520 \mathrm{~nm}$, and the amount of proline was calculated from the proline standard curve. The color of our reaction with ninhydrin was yellowish to deep yellow/pinkish, which indicated the presence of proline. We established a proline standard curve using different concentrations of proline in this experiment to verify the content of proline in our extracts. Similarly, the reaction of proline standards were also yellowish and pinkish (depending on the concentration of proline). 


\subsection{Statistical Analysis}

Analysis of variance (ANOVA) was carried out on the data for both genotypes, the four treatments, and two years, as a three-factor analysis [57]. ANOVA was also used for the two cultivars separately, as well as for the two sampling times combined, in order to observe the influence of treatments on the APX, POD, MDA, proline, and protein contents within each cultivar. Differences were inspected at a $p<0.05$ level of significance. The Tukey test and least significant difference (LSD) were used for means separation.

Author Contributions: B.T.: designed the experiment, investigation, completed the statistical analysis, writing-original draft preparation. C.J.: completed the statistical analysis, writing-original draft preparation, resources. M.L.: conceptualization, completed the statistical analysis, supervision, writing-review and editing, resources. M.J.M.: investigation, writing-original draft preparation. All authors have read and agreed to the published version of the manuscript.

Funding: This research did not receive any specific grant from funding agencies in the public, commercial, or not-for-profit sectors.

Acknowledgments: This research was funded by the National Research Foundation of South Africa, through the SARChI chair initiative.

Conflicts of Interest: The authors declare that they have no conflict of interest.

\section{References}

1. Arraiza, M.P.; Santamarta, J.C.; Ioras, F.; García-Rodríguez, J.L.; Abrudan, I.V.; Korjas, H.; Borála, G. (Eds.) Climate Change and Restoration of Degraded Land; Colegio de Ingenieros de Montes: Madrid, Spain, 2014.

2. Schoenholtz, S.; Miegroet, H.V.; Burger, J. A review of chemical and physiological properties as indicators of forest soil quality. Challenges and opportunities. Ecol. Manag. 2000, 138, 335-356.

3. Von Uexkull, H.R.; Mutert, E. Global extent, development and economic impact of acid soils. Plant Soil 1995, 171, 1-15. [CrossRef]

4. Venter, A.; Herselman, J.E.; VanderMerwe, G.M.E.; Steyn, C.; Beukes, D.J. Developing soil acidity maps for South Africa. In Proceedings of the 5th International Symposium on Soil Plant Interactions at Low pH, Bergville, South Africa, 12-16 March 2001; p. 21.

5. Roberts, V.G.; Smeda, Z. The distribution of soil fertility constraints in KwaZulu-Natal, South Africa. In Proceedings of the 5th International Symposium on Plant Soil Interactions at low $\mathrm{pH}$, Bergville, South Africa, 12-16 March 2001; p. 12.

6. Dewi-Hayati, P.K.; Sutoyo, A.; Syarif, A.; Prasetyo, T. Performance of maize single-cross hybrids evaluated on acidic soils. Int. J. Adv. Sci. Eng. Inf. Technol. 2014, 4, 30-33.

7. Koyama, H.; Toda, T.; Hara, T. Brief exposure to low-pH stress causes irreversible damage to the growing root in Arabidopsis thaliana: Pectin-Ca interaction may play an important role in proton rhizotoxicity. J. Exp. Bot. 2001, 52, 361-368. [PubMed]

8. Ghiimire, R.; Machado, S.; Bista, P. Soil pH, soil organic matter, and crop yields in winter wheat-summer fallow systems. Agron. J. 2017, 109, 707-717. [CrossRef]

9. Anderson, G.; Bell, R. Wheat grain-yield response to lime application: Relationships with soil pH and aluminium in Western Australia. Crop Pasture Sci. 2019, 70, 295-305. [CrossRef]

10. Long, A.; Zhang, J.; Yang, L.T.; Ye, X.; Lai, N.W.; Tan, L.L.; Lin, D.; Chen, L.S. Effects of low pH on photosynthesis, related physiological parameters and nutrient profile of Citrus. Front. Plant Sci. 2017, 8, 185. [CrossRef]

11. Schroeder, J.L.; Zhang, H.; Girma, K.; Raun, W.R.; Penn, C.J. Soil acidification from long-term use of nitrogen fertilizers on winter wheat. Soil Sci. Soc. Am. J. 2011, 75, 957-964. [CrossRef]

12. Tian, D.; Niu, S. A global analysis of soil acidification caused by nitrogen addition. Environ. Res. Lett. 2015, 10, 024019. [CrossRef]

13. Oertel, C.; Matschullat, J.; Zurba, K.; Zimmermann, F.; Erasmi, S. Greenhouse gas emissions from soils-A review. Geochemistry 2016, 76, 327-352. [CrossRef]

14. Bini, C.; Breslin, F. Soil acidification by acid rain in forest ecosystems: A case study in northern Italy. Sci. Total Environ. 1998, 222, 1-15. [CrossRef] 
15. Russell, A.E.; Laird, D.A.; Mallarino, A.P. Nitrogen fertilizer and cropping system impacts on soil quality in mid-western Mollisols. Soil Sci. Soc. Am. J. 2006, 70, 249-255.

16. Matsumoto, S.; Ogata, S.; Shimada, H.; Sasaoka, T.; Hamanaka, A.; Kusuma, G.J. Effects of pH-induced changes in soil physical characteristics on the development of soil water erosion. Geoscience 2018, 8, 134. [CrossRef]

17. Meda, A.R.; Cassidato, M.E.; Pavan, M.A.; Miyazawa, M. Alleviating soil acidity through plant organic compounds. Braz. Arch. Biol. Technol. 2001, 44, 185-189. [CrossRef]

18. Blake, L.; Goulding, K.W.T.; Mott, C.J.B.; Johnston, A.E. Changes in soil chemistry accompanying acidification over more than 100 years under woodland and grass at Rothamsted Experimental Station, UK. Eur. J. Soil Sci. 1999, 50, 401-412. [CrossRef]

19. Robles-Aguilar, A.A.; Pang, J.; Postma, J.A.; Schrey, S.D.; Lambers, H.; Jablonowski, N.D. The effect of pH on morphological and physiological root traits of Lupinus angustifolius treated with struvite as a recycled phosphorus source. Plant Soil 2019, 434, 65-78. [CrossRef]

20. Song, H.; Xu, X.; Wang, H.; Tao, Y. Protein carbonylation in barley seedling roots caused by aluminum and proton toxicity is suppressed by salicylic acid. Russ. J. Plant Physiol. 2011, 58, 653-659. [CrossRef]

21. Sharma, P.; Jha, A.B.; Dubey, R.S.; Pessarakli, M. Reactive oxygen species, oxidative damage, and antioxidative defence mechanisms in plants under stressful conditions. J. Bot. 2012, 217037. [CrossRef]

22. Zhang, Y.K.; Zhu, D.F.; Zhang, Y.P.; Chen, H.Z.; Xiang, J.; Lin, X.Q. Low pH-induced changes of antioxidant enzyme and ATPase activities in the roots of rice (Oryza sativa L.) seedlings. PLoS ONE 2015, 10, e0116971. [CrossRef]

23. Martins, N.; Gonçalves, S.; Romano, A. Metabolism and aluminum accumulation in Plantago almogravensis and P. algarbiensis in response to low $\mathrm{pH}$ and aluminum stress. Biol. Plant. 2013, 57, 325-331. [CrossRef]

24. Yang, M.; Huang, S.X.; Fang, S.Z.; Huang, X.L. Response of seedling growth of four Eucalyptus clones to acid and aluminum stress. Plant Nutr. Fertil. Sci. 2011, 17, 195-201.

25. Martins, N.; Osório, M.L.; Gonçalves, S.; Osório, J.; Romano, A. Differences in Al tolerance between Plantago algarbiensis and P. almogravensis reflect their ability to respond to oxidative stress. Biometals 2013, 26, 427-437. [CrossRef] [PubMed]

26. Liu, E.U.; Liu, C.P. Effects of simulated acid rain on the antioxidative system in Cinnamomum philippinense seedlings. Water Air Soil Poll. 2011, 215, 127-135. [CrossRef]

27. Chen, J.; Wang, W.H.; Liu, T.W.; Wu, F.H.; Zheng, H.L. Photosynthetic and antioxidant responses of Liquidambar formosana and Schima superba seedlings to sulfuric-rich and nitric-rich simulated acid rain. Plant Physiol. Biochem. 2013, 64, 41-51. [CrossRef] [PubMed]

28. Shi, Q.H.; Zhu, Z.J.; Juan, L.I.; Qian, Q.Q. Combined effects of excess Mn and low $\mathrm{pH}$ on oxidative stress and antioxidant enzymes in cucumber roots. Agric. Sci. China 2006, 5, 767-772. [CrossRef]

29. Long, A.; Huang, W.L.; Qi, Y.P.; Yang, L.T.; Lai, N.W.M.; Guo, J.X.; Chen, L.S. 2019. Low pH effects on reactive oxygen species and methylglyoxal metabolisms in citrus roots and leaves. BMC Plant Biol. 2019, $19,477$. [CrossRef]

30. Martins, N.; Gonçalves, S.; Palma, T.; Romano, A. The influence of low $\mathrm{pH}$ on in vitro growth and biochemical parameters of Plantago almogravensis and P. algarbiensis. Plant Cell Tissue Organ Cult. 2011, 107, 113-121. [CrossRef]

31. Hasanuzzaman, M.; Nahar, K.; Hossain, M.S.; Mahmud, J.A.; Rahman, A.; Inafuku, M.; Oku, H.; Fujita, M. Coordinated actions of glyoxalase and antioxidant defense systems in conferring abiotic stress tolerance in plants. Int. J. Mol. Sci. 2017, 18, 200. [CrossRef]

32. Bhuyan, M.H.M.B.; Hasanuzzaman, M.; Mahmud, J.A.; Hossain, S.; Bhuiyan, T.F.; Fujita, M. Unraveling morphophysiological and biochemical responses of Triticum aestivum L. to extreme $\mathrm{pH}$ : Coordinated actions of antioxidant defence and glyoxalase systems. Plants 2018, 8, 24. [CrossRef]

33. Hou, Y.; Guo, Z.; Yi, Y.; Li, H.-N.; Li, H.-G.; Chen, L.; Ma, H.; Zhang, L.; Lin, J.W.; Zhong, M. Effects of cold acclimation and exogenous phytohormones abscisic acid treatment on physiological indicators of winterness wheat. J. Plant Sci. 2010, 5, 125-136.

34. Turhan, A.; Ozmen, N.; Kuscu, H.; Serbeci, S.M.; Seniz, V. Influence of rootstocks on yield and fruits characteristics and quality of watermelon. Hortic. Environ. Biotechnol. 2012, 53, 336-341. [CrossRef]

35. Firscher, R.A. Number of kernels in wheat crops and the influence of solar radiation and temperature. J. Agric. Sci. 1985, 105, 447-461. [CrossRef] 
36. Dreccer, M.F.; Fainges, J.; Whish, J.; Ogbonnaya, F.C. Comparison of sensitive stages of wheat, barley, canola, chickpea and field pea to temperature and water stress across Australia. Agric. For. Meteorol. 2018, 248, 275-294. [CrossRef]

37. Nikolaeva, M.K.; Maevskaya, S.N.; Shugaev, A.G.; Bukhov, N.G. Effect of drought on chlorophyll content and antioxidant enzyme activities in leaves of three wheat cultivars varying in productivity. Russ. J. Plant. Physiol. 2010, 57, 87-95. [CrossRef]

38. Verbruggen, N.; Hermans, C. Proline accumulation in plants: A review. Amino Acids 2008, 35, 753-759. [CrossRef]

39. Hayat, S.; Hayat, Q.; Alyemeni, M.N.; Wani, A.S.; Pichtel, J.; Ahmad, A. Role of proline under changing environments. Plant Signal. Behav. 2012, 7, 1-11. [CrossRef] [PubMed]

40. Ogagaoghene, A.J. $\mathrm{pH}$ level, ascorbic acid, proline and soluble sugar as bio-indicators for pollution. Chem. Search J. 2017, 8, 41-49.

41. Naing, A.H.; Lee, D.B.; Ai, T.N.; Lim, K.B.; Kim, C.K. Enhancement of low pH stress tolerance in anthocyanin-enriched transgenetic Petunia overexpressing RsMYB1 gene. Front. Plant Sci. 2018, 9, 1124. [CrossRef] [PubMed]

42. Hoque, M.A.; Banu, M.N.A.; Okuma, E.; Amako, K.; Nakamura, Y.; Shimoishi, Y.; Murata, Y. Exogenous proline and glycinebetaine increase $\mathrm{NaCl}$-induced ascorbate-glutathione cycle enzyme activities, and proline improves salt tolerance more than glycinebetaine in tobacco Bright Yellow-2 suspension-cultures cells. J. Plant Physiol. 2007, 164, 1457-1468. [CrossRef]

43. Sanmartin, M.; Drogoudi, P.A.; Lyons, T.; Pateraki, I.; Barnes, J.; Kanellis, A.K. Over-expression of ascorbate oxidase in the apoplast to transgenic tobacco results in altered ascorbate and glutathione redox states and increased sensitivity to ozone. Planta 2003, 216, 918-928. [CrossRef]

44. De Tullio, M.C. Antioxidants and redox regulation: Changing notions in a changing world. Plant Physiol. Biochem. 2010, 48, 289-291. [CrossRef] [PubMed]

45. Bremner, J.M. Determination of nitrogen in soil by the Kjeldahl method. J. Agric. Sci. 1960, 55, 11-33. [CrossRef]

46. Bray, R.H.; Kurtz, L.T. Determination of total, organic, and available forms of phosphorus in soils. Soil Sci. 1945, 59, 39-45. [CrossRef]

47. Miller, R.O.; Gavlak, R.; Horneck, D. Plant, Soil and Water Reference Methods for the Western Region; WREP: Western Rural Development Center: Corvallis, OR, USA, 2013; Volume 125.

48. Walkley, A.; Black, I.A. An examination of the Degtjareff method for determining ssoil organic matter, and a proposed modification of the chromi acid titration method. Soil Sci. 1934, 37, 29-38. [CrossRef]

49. Bouyoucos, G.J. Directions for Making Mechanical Analysis of Soils by the Hydrometer Method. Soil Sci. 1936, 4, 225-228. [CrossRef]

50. Pukacka, S.; Ratajczak, E. Production and scavenging of reactive oxygen species in Fagus sylvatica seeds during storage at varied temperature and humidity. J. Plant Physiol. 2005, 162, 873-885. [CrossRef]

51. Mishra, N.P.; Mishra, R.K.; Singhal, G.S. Changes in the activities of anti-oxidant enzymes during exposure of intact wheat leaves to strong visible light at different temperatures in the presence of protein synthesis inhibitors. Plant Physiol. 1993, 102, 903-910. [CrossRef]

52. Zeislin, N.; Ben-Zaken, R. Peroxidases, phenylalanine ammonia-lyase and lignification in peduncles of rose flowers. Plant Physiol. Biochem. 1991, 29, 147-151.

53. Bradford, M.M. A rapid and sensitive method for the quantitation of microgram quantities of protein utilizing the principle of protein-dye binding. Anal. Biochem. 1976, 72, 248-254. [CrossRef]

54. Heath, R.L.; Packer, L. Photoperoxidation in isolated chloroplasts. I. Kinetics and stoichiometry of fatty acid peroxidation. Arch. Biochem. Biophys. 1968, 125, 189-198. [CrossRef]

55. Carillo, P.; Gibon, Y. Protocol: Extraction and Determination of Proline. 2011. Available online: https://www. researchgate.net/publication/211353600_PROTOCOL_Extraction_and_determination_of_proline (accessed on 1 September 2020). 
56. Hummel, I.; Pantin, F.; Sulpice, R.; Piques, M.; Rolland, G.; Dauzat, M.; Christophe, A.; Pervent, M.; Bouteillé, M.; Stitt, M.; et al. Arabidopsis plants acclimate to water deficit at low cost through changes of carbon usage: An integrated perspective using growth, metabolite, enzyme, and gene expression analysis. Plant Physiol. 2010, 154, 357-372. [CrossRef]

57. Agrobase. Agrobase Generation II, Agronomix; Agrobase: Winnipeg, MB, Canada, 2014.

Publisher's Note: MDPI stays neutral with regard to jurisdictional claims in published maps and institutional affiliations.

(C) 2020 by the authors. Licensee MDPI, Basel, Switzerland. This article is an open access article distributed under the terms and conditions of the Creative Commons Attribution (CC BY) license (http://creativecommons.org/licenses/by/4.0/). 